\title{
T.C. Sağlık Bakanlığı Ulusal Medikal Kurtarma Ekibi (UMKE) Çalışanlarında Algılanan Stres Düzeyleri Üzerinde Otantik Liderlik Davranışları Etkisinin İncelenmesi: İstanbul İli Örneği
}

\author{
Ali TOPAL ${ }^{1}$, Muhittin DEMIRKASIMOĞLU ${ }^{1 *}$
}

Öz

T.C. Sağlık Bakanlığı İstanbul ili ulusal medikal kurtarma ekibi mensuplarının (UMKE), stres algılarının göstermiş oldukları otantik liderlik davranışları ile hangi düzeyde etkilendiklerinin tespit edilmesi bu araştırmanın amacını oluşturmaktadır. Çalışmanın evrenini ise T.C. Sağlık Bakanlığı İstanbul ili UMKE örneklemini T.C. Sağlık Bakanlığı taşra teşkilatı İstanbul ili UMKE 435 personelden oluşturmaktadır. Bilgi ve veriler Cohen (1983) tarafından geliştirilen ve (Eskin, 2013) tarafından Türkçeye uyarlanan Algılanan Stres Ölçeği 5'li Likert tipi bir ölçek ile Walumbwa (2008) tarafından geliştirilmiş olan "Otantik Liderlik Ölçeği" ile toplanmıştır. Tanımlayıcı araştırma modeli ile gerçekleştirilen çalışmada bilgi ve verilerin analizinde tanımlayıcı istatistikler, Pearson Korelasyon ile Regresyon analizleri kullanılmıştır. Yapılan Pearson Korelasyon analizi sonucunda bazılarında zayıfta olsa algılanan stres ve otantik liderlik boyutları yani bağımlı ve bağımsız değişkenler arasında ilişkinin olduğu tespit edilmiştir. Bunun yanı sıra bağımlı değişken, bağımsız değişken ile arasındaki ilişki derecesinin ne olduğunu saptamak üzere Regresyon analizi yapılmıştır. Bunun sonucu olarak ilişkilerde şeffaflık boyutu $(b=0,274, p<0,05)$ Stres/Rahatsızlık algısı boyutunu pozitif etkilemekte iken içselleştirilmiş ahlak anlayışı, bilgiyi dengeli değerlendirme, öz farkındalık boyutları etkilememektedir $(p>0,05)$. Stres/Rahatsızlık algısı boyutundaki değişimin $(\% 10,01)$ 'ini ilişkilerde şeffaflık boyutu açıklamaktadır. Yetersiz öz yeterlilik algısı boyutundaki değişimin (\%13,99)'unu ilişkilerde şeffaflık ve öz farkındalık boyutları açıklamaktadır. Araştırma sonucuna göre bütün hipotezlerin kabul edilmesi mümkündür.

Anahtar kelimeler: Algılanan Stres, Otantik Liderlik Davranışları, UMKE çalışanları.

\section{Examining the Effect of Authentic Leadership Behaviors on Perceived Stress Levels in National Medical Rescue Team (UMKE) Workers in the Ministry of Health: Example of İstanbul}

\begin{abstract}
The aim of this study is to determine the level of effectiveness of the members of national medical rescue team (UMKE) of Istanbul province on their authentic leadership behaviors. The universe of the study is T.C. Ministry of Health UMKE in Istanbul province, sample T.C. The provincial organization of the Ministry of Health is composed of 435 personnel from the UMKE in Istanbul. The information and data were developed by Cohen (1983) and was developed by Walumbwa (2008) with a Perceptual Stress Scale 5-point Likert-type scale adapted to Turkish by (Eskin 2013). Collected with. In the study carried out with the descriptive research model, descriptive statistics, Pearson Correlation, and Regression
\end{abstract}

\footnotetext{
${ }^{1}$ Sağlık Bakanlığı, Yönetim Hizmetleri Gn.Müd.,Ankara,

*ilgili yazar / Corresponding author: mdemirkasimoglu@yahoo.com

Gönderim Tarihi / Received Date: 24.02.2020

Kabul Tarihi / Accepted Date: 11.06.2020
} Stres Düzeyleri Üzerinde Otantik Liderlik Davranışları Etkisinin İncelenmesi: İstanbul İli Örneği. Resilience, 159-168. 
analyzes were used in the analysis of information and data. As a result of Pearson Correlation analysis, it was determined that there was a relationship between perceived stress and authentic leadership dimensions, that is, dependent and independent variables, in some of them. In addition, regression analysis was carried out to determine the degree of relationship between dependent variable and independent variable. The transparency size in relationships as a result of $(b=0.274, p<0.05)$ Stress / While the discomfort perception of the size of the positive effects of internalized morality, knowledge and balanced assessment, self does not affect awareness dimensions ( $p>0.05$ ). Transparency in relationships explains the change in the stress/discomfort perception dimension (10.01\%). Transparency and selfawareness dimensions in relations explain the change $(13.99 \%)$ of the inadequate selfefficacy perception dimension. According to the research result, it is possible to accept all hypotheses.

Keywords: Authentic Leadership Behaviors, Perceived Stress, UMKE workers.

\section{GíRiş}

Dünyada ve ülkemizde sağlık sektörü mensupları yoğun stres altında mesleklerini icra etmeye çalışmaktadır. Özellikle dünyaya öncülük eden T.C.Sağlık Bakanlığı Acil Sağlık Hizmetleri Genel Müdürlüğüne bağlı olarak görev yapan fedakâr UMKE görevleri gereği olağandışı durumlar, afetler gibi çalıştıkları yoğun stresli iş ortamında sergilemiş oldukları davranış biçimleri önem arz etmektedir. Bu çalışmanın amacı UMKE mensuplarının stres algılarının göstermiş oldukları otantik liderlik davranışları ile hangi düzeyde etkilendiklerinin tespit edilmesidir. Araştırmamız T.C.Sağlık Bakanlığı İstanbul ili ulusal medikal kurtarma ekibi çalışanları ile gerçekleştirilmiştir.

\section{STRES}

Stres kelimesi Latincede "estrictia" olarak geçmektedir. Hayatın var oluşundan bu yana insanların karşı karşıya olduğu stres, 17. y.y'da felaket, bela, dert, keder şeklinde ifade edilirken 18 ve 19. y.y'da bireye, ve ruhsal yapısına yönelik güç, baskılama ve zor kullanma anlamında ifade edilmiştir. (Güçlü, 2001).

Selye stresi şöyle belirmiştir, kişide var olan enerjinin yok oluşuna neden olmaktadır. Normalde strese adapte olmak için kullanılan enerji yok olma özelliğini taşımaktadır. Bireylere zarar veren stres fizyolojik olarak hücrelerin yıpranmasına ve yaşlanmasına zarar neden olmaktadır. Ayrıca stresin olumlu özelliklere ve olumsuz özellikleri sahip olduğu belirtilmektedir (Selye,1974). Bu nedenle stres iş görenlerin iş yapma yeteneklerini ve kapasitelerini pozitif yönde değiştirirse "olumlu stres", negatif şekilde değiştirirse "olumsuz stres" olarak da tanımlanabilmektedir (Quıck / Qoıck, 1984).

Stres çalışmaları başladığından itibaren birçok tanımlamalar yapılmıştır. Stres kavramını üç temel yaklaşım (Fizyolojik veya biyolojik, Mühendislik ve Psikolojik) olarak niteleyen Cox ve Griffiths (1995; akt., Mark ve Smith, 2008) tüm tanımların bu temel üç yaklaşıma dayandığını belirtmiştir. Fizyolojik veya biyolojik yaklaşım organizmada oluşan değişiklikleri kapsamaktadır. Mühendislik yaklaşımında ise bireyin üzerinde çevrenin ve etrafında gerçekleşen olayları kapsamaktadır. Psikolojik yaklaşım ise çevre ile gerçekleşen durumların bireyin iç dünyasındaki etkilerini kapsamaktadır (Cox ve Griffiths 1995; akt., Mark ve Smith, 2008).

Stresin en yaygın olduğu durumlardan biri de iş ortamıdır. Birçok araştırmacı tarafından iş stresi tanımlamaları yapılmıştır. Örneğin, iş görenin İş stresi iş görenin çalışma ortamından etkilenmesi sonucu üzerinde oluşan gerilimdir (Lazarus, 1991). 
İş stresi, örgüt çalışanları ve örgütün kendisi için ciddi sorun oluşturmaktadır. İş stresi, iş ortamındaki zorluk ve yetersizlikler, fiziki stresle mücadeleyi zayıflatmakla birlikte yetersiz duruma getirerek hastalıkla sonuçlanan istenmeyen bir durumdur (Leong, 1996). Eskin ve arkadaşlarının yapmış olduğu çalışmalarında stres kavramının yetersiz öz-yeterlik ve stres/rahatsızlık algısı olmak üzere iki boyutlu bir yapı olduğunu belirtmişlerdir (Eskin, Harlak, Demirkıran ve Deraboy, 2013).

\section{OTANTIK LIDERLIK}

Son günlerde otantik liderlik davranışlarına duyulan gereksinim, örgütlerin ve iş görenlerin güvenilir, doğru, dürüst, proaktif ve ahlaki değerler sahibi olma istek ve arzularından gelişmiştir (Işkın ve Kaygın, 2016). Otantik liderlik davranışı bireylerin kendi içlerinde oluşturdukları inançlar, değerler ve tercihlerini başkalarının beklentilerine göre şekillendirmemesidir (Gardner, 2005). Kernis (2003) otantik liderlik davranışlarının, bireyin gün içinde kendi doğrularıyla hareket etmesi şeklinde ifade etmektedir. Otantik liderlik davranışlarında; "olduğu gibi görünme, göründüğü gibi olma", tutum ve inançları arasında uyumluluk, kişinin pozitif ve negatif yönlerini bilerek öz farkındalığı ile bulunduğu yere katkıda bulunmasıdır (Walumbwa, 2008). Harter (2002) otantikliği şöyle bildirmektedir; kişinin hayat boyu edindiği tecrübesi (duygu, fikir, öncelik, gereksinim, inanç veya arzularını kabullenmesi) ile kişisel özelliklerinin farkındalığını kapsayarak uyumlu bir şekilde, hissettikleri ile düşünerek hareket etmektir. Otantik davranışı kişinin tercihleri, intiyaçları ve değer yargılarına uygun bir biçimde davranış sergilemesi olarak tanımlanmaktadır (Kernis, 2003). Otantik liderlik, bireyin kendisine karşı dürüst olmasını bir zorunluluk haline getirmek yerine o bireyin gerçek isteklerini, eğilimlerini ve duygularını özgür bir biçimde ifade etmesini sağlamaktadır.

Otantik liderliğin dört bileşeni vardır (Keser, 2013). Bunlar "1-Öz Farkındalık, 2-Bilgiyi Dengeli ve Tarafsız Değerlendirme, 3-İçselleştirilmiş Ahlak Anlayışı, 4-ïlişkilerde Şeffafılık "olarak sıralanabilir.

\section{1. Öz Farkındalık}

Öz farkındalık, insanın gereksinimleri, inandıkları, hissettikleri, karakteri ve eylemlerini kapsamaktadır. Öz farkındalık ruh sağlığının önemli bir etkenidir. (Kernis, 2003). Öz farkındalık düzeyi fazla olanların kendilerine uyum göstermeleri durumunda gerçekçi olacakları böylece etraflarında oluşan belirsizliklerin yok olması ile güven duygusunun oluşacağı varsayılmaktadır. Kişilerin bilmedikleri ya da tahmin edemedikleri durumlarda tedirgin oldukları düşünüldüğünde otantik liderlik davranışlar bu tedirginliği azaltabilir. Bunun yanı sıra kişinin vereceği kararların doğru ve güvenilir olmasını sağlayabilir (Yener, 2018).

\subsection{Bilgiyi Dengeli ve Tarafsız Değerlendirme.}

Otantik liderlik davranışı sergileyenler kendilerine ait bilgiler ile çevreden elde ettikleri bilgileri objektif şekilde yorumlamalı, değerlendirmeli ve beceri seviyelerini daha etkin hale getirmelidir. Farklı iş sahalarında görevli çalışanlardan bilgiler alınarak; karar aşamasında ihtiyaç duyulan bilgileri elde etmesi ve objektif şekilde değerlendirmesi gerekmektedir (Yeşiltaş, 2013).

\section{3. İçselleştirilmiş Ahlak Anlayışı}

Otantik liderlik davranışları ile lider kendinde var olan ahlak anlayışını ve etik değerlerini örgütün tamamına işlemektedir. Böylece otantik liderlik davranışlarının ahlaki değerleri taşıması, içinde bulunulan örgütün etik anlayışının yaygınlaşmasına neden olarak kalitenin artışına etki sağlayacaktır. (Yeşiltaş vd., 2013). Kişinin yaşadığı topluma uygun şekilde durumları ve gelişmeleri anlama ve tavır sergilemesi içselleştirilmiş ahlak anlayışını göstermektedir. Süreklilik kazanan bu durum otantik liderlik davranışı gösterenlerde zarar görseler bile bu anlayışı devam ettirmelerini sağlar (Yener,2018). 


\section{4. İlişkide Şeffaflık}

Otantik liderlik davranışı sergileyenler pozitif yönlü duygularını etraflarına gösterme konusunda zararlı bölümleri süzgeçten geçirerek kontrollü şekilde şeffaflığını sağladıkları görülmüştür. Bu durum, ilişkilerde şeffaflığın otantik liderlik davranışları sergileyenlerde kendine has amaçlarını, kimliğini, inançlarını, yargılarını ve duygularını açıkça gösterebilmesine bağlanabilmektedir (Gardner, 2005).

\section{YÖNTEM}

\subsection{Araştırmanın Modeli ve Hipotezleri}

Araştırma tanımlayıcı araştırma modeli ile gerçekleştirilmiştir. Çalışmada bağımlı ve bağımsız değişkenler arasındaki ilişinin yönü ve derecesinin tanımlanması amaçlanmaktadır. Bu bağlamda söz konusu değişkenlerin ilişkilerine ilişkin kavramsal model Şekil 1'deki gibi ifade edilebilir.

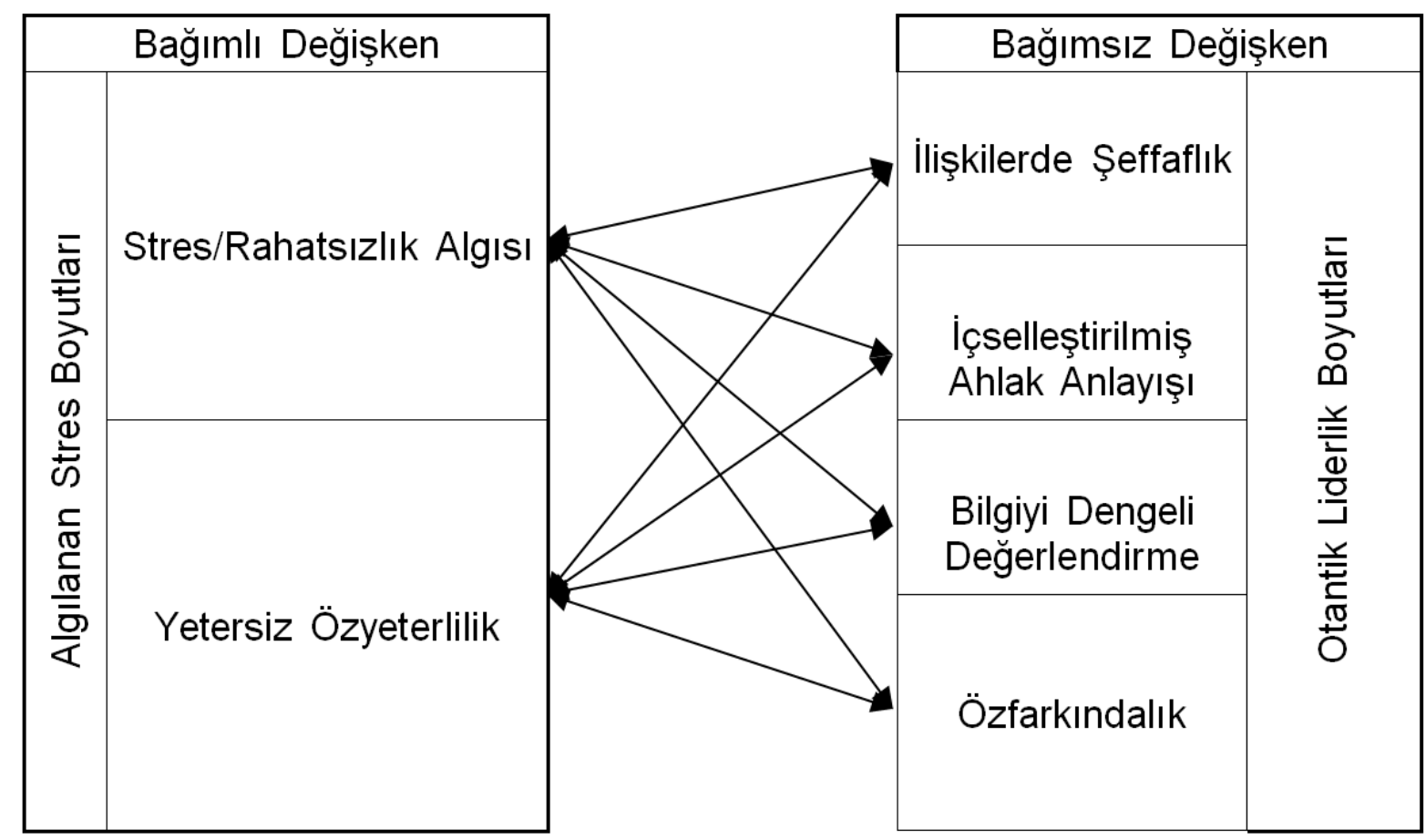

Şekil 1. Araştırmanın kavramsal modeli

Bu kavramsal modele dayanarak araştırmanın hipotezleri aşağıdaki şekilde sıralanabilir:

\subsection{Hipotez:}

H1: T.C. Sağlık Bakanlığı Ulusal Medikal Kurtarma Ekibi (UMKE) çalışanlarında algılanan stres düzeyleri otantik liderlik davranışları arasında bir ilişki vardır

Bu ana hipoteze bağlı olarak geliştirilen alt hipotezler de şunlardır:

h1.1. Sağlık Bakanlığı Ulusal Medikal Kurtarma Ekibi (UMKE) çalışanlarında algılanan stres düzeyleri ile ilişkilerde şeffaflık olduğunu düşünmeleri arasında bir ilişki vardır. 
h1.2. Sağlık Bakanlığı Ulusal Medikal Kurtarma Ekibi (UMKE) çalışanlarında algılanan stres düzeyleri ile içselleştirilmiş ahlak anlayışına sahip olduklarını düşünmeleri arasında bir ilişki vardır.

h1.3. Sağlık Bakanlığı Ulusal Medikal Kurtarma Ekibi (UMKE) çalışanlarında algılanan stres düzeyleri ile bilgiyi dengeli değerlendiklerini düşünmeleri arasında bir ilişki vardır.

h1.4. Sağlık Bakanlığı Ulusal Medikal Kurtarma Ekibi (UMKE) çalışanlarında algılanan stres düzeyleri ile özfarkındalığa sahip olduklarını düşünmeleri arasında bir ilişki vardır.

\subsection{Evren ve Örneklem}

Bu çalışmanın hedef evreni T.C. Sağlık Bakanlığı İstanbul İı Sağlık Müdürlüğü ulusal medikal kurtarma ekibinin (UMKE) tamamıdır. Ancak araştırmacıların ulaşmak istemelerine rağmen ulaşılma güçlüğü nedeniyle, ulaşılabilir ya da somut evreni (445) personel oluşturmaktadır. Araştırmada basit tesadüfî örnekleme yöntemi kullanılmıştır. Örnek büyüklüğü gönüllü (252) kişi olarak belirlenmiş ve 2017 yılı yaz döneminde uygulanmıştır. Çok sayıda cevapsız soru olan veya aynı cevap verilmiş (14) anket geçersiz sayılmış ve (238) kişi üzerinden analiz yapılmıştır.

\subsection{Veri Toplama Aracı}

Bilgi ve verilerin toplanmasında algılanan stres seviyesini ölçen (16) soru ve otantik liderlik davranışlarını ölçen (16) soru olmak üzere toplamda (32) sorudan oluşan bir anket formu kullanılmıştır.

Cohen (1983) tarafından geliştirilen ve (Eskin, 2013) tarafından Türkçeye uyarlanan Algılanan Stres Ölçeği (5)'li Likert tipi bir kullanılmıştır. Ölçek maddeleri "Hiçbir zaman (0)" ile "Çok sık (4)" arasında değişen seçeneklerden birisi işaretlenerek doldurulmaktadır. Ölçekte bulunmakta olan maddelerden olumlu ifade içeren (7) tanesi ters olarak puanlanmaktadır. Ölçekten alınabilecek puanlar (0) ile (56) arasında değişmekte ve yüksek puan stres algısının yüksek olduğuna işaret etmektedir. Eskin (2013) Yetersiz Öz Yeterlik Algısı ve Stres/Rahatsızlık algısı olarak adlandırılan iki alt boyutunun bulunduğunu ve iç tutarlık katsayısının (0.84), test-tekrar test güvenirlik katsayısının (0.87) olduğunu belirtmektedir. Otantik Liderlik Ölçeği 16 maddeden oluşan (5)'li likert tipinde bir ölçektir (Walumbwa, 2008: 89-26). Ölçeğin alt boyutları; lider özfarkındalığı, ilişkilerde şeffaflık, içselleştirilmiş ahlak anlayışı ve karar alma şeklindedir. Ölçeğin bileşenlerinin güvenirlik değerleri; özfarkındalık (0.73), ilişkilerde şeffaflık (0.77), içselleştirilmiş ahlak anlayışı (0.73) ve bilginin dengeli değerlendirilmesi (0.70) olarak bulunmuştur. Bu çalışmada Çeri-Booms (2009) tarafından geliştirilen ölçeği Türkçeye uyarlamıştır. Bu çalışmada, ölçek dört bileşenden oluşmaktadır. Bunlar; özfarkındalık, ilişkilerde şeffafılı, dengeli süreç ve etik/ahlaktır. Ölçek (16) maddeden oluşmaktadır. Ölçeğin tümü için güvenilirlik değeri (0.90) olarak ifade edilmiştir.

\section{BULGULAR}

Veriler ölçek puanlarının ilişkisi Pearson korelasyon testi ile, bağımlı değişkenin bağımsız değişkenden etkilenmesi derecesi ise regresyon testi ile analiz edilmiştir. 
T.C. Sağlık Bakanlığı Ulusal Medikal Kurtarma Ekibi (UMKE) Çalışanlarında Algılanan Stres Düzeyleri Üzerinde Otantik Liderlik Davranışları Etkisinin İncelenmesi: İstanbul İli Örneği

Examining the Effect of Authentic Leadership Behaviors on Perceived Stress Levels in National Medical Rescue Team (UMKE) Workers in the Ministry of Health: Example of Istanbul

Tablo 1.1. Katılımcıların Demografik Özellikler Dağılımı

\begin{tabular}{|c|c|c|c|c|}
\hline $\begin{array}{l}\text { Demografik } \\
\text { Özellikler }\end{array}$ & & $\mathrm{f}$ & $\%$ & $\%$ \\
\hline \multirow[t]{4}{*}{ Cinsiyet } & Kadın & (197) & $(45,2)$ & $(46,7)$ \\
\hline & Erkek & $(224)$ & $(51,5)$ & $(53,3)$ \\
\hline & Toplam & $(421)$ & $(96,7)$ & $(100,0)$ \\
\hline & Cevapsız & $(14)$ & $(3,3)$ & \\
\hline \multirow[t]{7}{*}{\begin{tabular}{|l|} 
Yaş \\
$(29,21 \pm 7,77)$ \\
\end{tabular}} & 20 Yaş ve Altı & (32) & $(7,0)$ & $(7,8)$ \\
\hline & 21-30 Yaş & $(215)$ & $(49,9)$ & $(55,5)$ \\
\hline & 31-40 Yaş & $(105)$ & $(24,1)$ & $26,8)$ \\
\hline & 41-50 Yaş & $(36)$ & $(8,0)$ & $(8,9)$ \\
\hline & 51 Yaş ve Üzeri & (3) & $(0,9)$ & $(1,0)$ \\
\hline & Toplam & (391) & $(89,9)$ & $(100,0)$ \\
\hline & Cevapsız & (44) & $(10,1)$ & \\
\hline \multirow[t]{5}{*}{ Medeni Durum } & Bekâr & $(228)$ & $(52,5)$ & $(54,5)$ \\
\hline & Evli & $(172)$ & $(41,2)$ & $(42,8)$ \\
\hline & Boşanmış & (19) & $(2,6)$ & $(2,7)$ \\
\hline & Toplam & $(419)$ & $(96,3)$ & $(100,0)$ \\
\hline & Cevapsız & (16) & $(3,7)$ & \\
\hline \multirow[t]{7}{*}{ Eğitim Durumu } & illköğretim & $(4)$ & $(0,9)$ & $(1,0)$ \\
\hline & Lise & (128) & $(30,0)$ & $(31,4)$ \\
\hline & Meslek Yüksekokulu & $(172)$ & $(40,3)$ & $(42,3)$ \\
\hline & Lisans & $(79)$ & $(18,5)$ & $(19,4)$ \\
\hline & Lisansüstü & $(24)$ & $(5,6)$ & $(5,9)$ \\
\hline & Toplam & $(407)$ & $(95,3)$ & $(100,0)$ \\
\hline & Cevapsız & $(20)$ & $(4,7)$ & \\
\hline \multirow[t]{7}{*}{ Meslek } & Acil Tıp Teknisyeni & (131) & $(30,2)$ & $(31,5)$ \\
\hline & $\begin{array}{|lll|}\text { Ambulans ve Acil Bakım } \\
\text { Teknikeri }\end{array}$ & $(122)$ & $(28,1)$ & $(29,3)$ \\
\hline & Doktor & $(21)$ & $(4,4)$ & $(4,6)$ \\
\hline & Ambulans Sürücüsü & $(51)$ & $(11,7)$ & $(12,2)$ \\
\hline & Diğer Personel & (92) & $(21,3)$ & $(22,2)$ \\
\hline & Toplam & $(417)$ & $(95,8)$ & $(100,0)$ \\
\hline & Cevapsız & $(18)$ & $(4,2)$ & \\
\hline \multirow[t]{8}{*}{ Çalışma Süresi } & $0-5$ YII & $(232)$ & $(54,8)$ & $(57,8)$ \\
\hline & $5-10 Y_{I I}$ & $(94)$ & $(22,2)$ & $(23,5)$ \\
\hline & $10-15$ YII & (39) & $(8,7)$ & $(9,1)$ \\
\hline & $15-20 Y_{I I}$ & (22) & $(4,7)$ & $(4,9)$ \\
\hline & $20-25$ YII & (13) & $(3,0)$ & $(3,2)$ \\
\hline & 25 Yıldan Fazla & (7) & $(1,4)$ & $(1,5)$ \\
\hline & Toplam & $(407)$ & $(94,8)$ & $(100,0)$ \\
\hline & Cevapsız & $(28)$ & $(6,6)$ & $(6,8)$ \\
\hline Toplam & & $(435)$ & $(100,0)$ & \\
\hline
\end{tabular}

Tablo 1'de araştırmaya katılan UMKE çalışanların demografik özellikleri görülmektedir. 
Tablo 2. Algılanan stres, Otantik Liderlik Boyutlarına İlişkin Betimleyici İstatistikler

\begin{tabular}{|c|c|c|c|c|c|c|c|}
\hline$n=238$ & Minimum & Maksimum & Ortalama & $\begin{array}{c}\text { Std. } \\
\text { Sapma }\end{array}$ & Düzey \% & Çarpıklık & Basıklık \\
\hline $\begin{array}{l}\text { Stres/Rahatsızlık } \\
\text { Algısı }\end{array}$ & (10) & (30) & $(20,32)$ & $(4,04)$ & $(67,7)$ & $(0,62)$ & $(-0,13)$ \\
\hline $\begin{array}{l}\text { Yetersiz } \\
\text { Özyeterlilik Algısı }\end{array}$ & (10) & (30) & $(22,21)$ & $(4,17)$ & $(74,0)$ & $(-0,46)$ & $(-0,05)$ \\
\hline Algılanan Stres & (37) & (86) & $(63,17)$ & $(8,79)$ & $(73,5)$ & $(-0,06)$ & $(0,03)$ \\
\hline $\begin{array}{l}\text { İlişkilerde } \\
\text { Şeffaflık }\end{array}$ & (8) & (25) & $(18,72)$ & $(3,70)$ & $(74,9)$ & $(-0,38)$ & $(-0,15)$ \\
\hline $\begin{array}{l}\text { İçselleştirilmiş } \\
\text { Ahlak Anlayışı }\end{array}$ & (6) & (20) & $(14,89)$ & $(2,92)$ & $(74,4)$ & $(-0,38)$ & $(0,06)$ \\
\hline $\begin{array}{l}\text { Bilgiyi Dengeli } \\
\text { Değerlendirme }\end{array}$ & (5) & (15) & $(11,15)$ & $(2,19)$ & $(74,4)$ & $(-0,24)$ & $(-0,27)$ \\
\hline Özfarkındalık & (7) & (20) & $(15,07)$ & $(2,90)$ & $(75,4)$ & $(-0,28)$ & $(-0,13)$ \\
\hline Otantik Liderlik & (29) & (80) & $(59,84)$ & $(9,78)$ & $(74,8)$ & $(-0,29)$ & $(0,15)$ \\
\hline
\end{tabular}

Tablo 2'de algılanan stres ve otantik liderlik puanlarının betimleyici istatistikleri görülmektedir. İlişkilerde şeffaflık puan ortalaması $(18,72 \pm 3,70)$, içselleştirilmiş ahlak anlayışı puan ortalaması $(14,89 \pm 2,92)$, bilgiyi dengeli değerlendirme puan ortalaması $(11,15 \pm 2,19)$, otantik liderlik puan ortalaması da $(59,84 \pm 9,78)$ olup, algılanan stres puan ortalaması $(63,17 \pm 8,79)$ 'dur. Stres/Rahatsızlık algısı puan ortalaması $(20,32 \pm 4,04)$, yetersiz özyeterlilik puan ortalaması $(22,21 \pm 4,17)$, algılanan stres puan ortalaması $(63,17 \pm 8,79)$ 'dur.

Tablo 3. Algılanan stres, Otantik Liderlik Puanlarının İlişkisi

\begin{tabular}{lcccccc}
\hline & & $\begin{array}{c}\text { İlişkilerde } \\
\text { Şeffaflık }\end{array}$ & $\begin{array}{c}\text { İçselleştirilmiş } \\
\text { Ahlak Anlayş̧ı }\end{array}$ & $\begin{array}{c}\text { Bilgiyi Dengeli } \\
\text { Değerlendirme }\end{array}$ & Özfarkındalık & $\begin{array}{c}\text { Otantik } \\
\text { Liderlik }\end{array}$ \\
\hline $\begin{array}{l}\text { Stres/Rahatsızlık } \\
\text { Algısı }\end{array}$ & $\mathrm{r}$ & $\left(, 307^{* *}\right)$ & $\left(, 283^{* *}\right)$ & $\left(, 191^{* *}\right)$ & $\left(, 225^{* *}\right)$ & $\left(, 295^{* *}\right)$ \\
& $\mathrm{p}$ & $(, 000)$ & $(, 000)$ & $(, 000)$ & $(, 000)$ & $(, 000)$ \\
\hline Yetersiz & $\mathrm{r}$ & $\left(, 353^{* *}\right)$ & $\left(, 305^{* *}\right)$ & $\left(, 253^{* *}\right)$ & $\left(, 288^{* *}\right)$ & $\left(, 362^{* *}\right)$ \\
Özyeterlilik & $\mathrm{p}$ & $(, 000)$ & $(, 000)$ & $(, 000)$ & $(, 000)$ & $(, 000)$ \\
Algısı & $\mathrm{r}$ & $\left(, 467^{* *}\right)$ & $\left(, 439^{* *}\right)$ & $\left(, 349^{* *}\right)$ & $\left(, 426^{* *}\right)$ & $\left(, 513^{* *}\right)$ \\
\hline \multirow{2}{*}{ Algılanan Stres } & $\mathrm{p}$ & $(, 000)$ & $(, 000)$ & $, 000)$ & $(, 000)$ & $(, 000)$ \\
\hline
\end{tabular}

${ }^{* *} p<0,01{ }^{*} p<0,05$ anlamlı ilişki var, $p>0,05$ anlamlı ilişki yok

Tablo 3'de Algılanan stres, Otantik Liderlik Puanları görülmektedir. Stres/Rahatsızlık algısı ile ilişkilerde şeffaflık $(r=0,307)$, otantik liderlik algıları $(r=0,295)$ arasında pozitif yönlü orta; yetersiz özyeterlilik algısı ile ilişkilerde şeffaflık $(r=0,353)$, içselleştirilmiş ahlak anlayışı algıları $(r=0,305)$; otantik liderlik $(r=0,362)$ puanları arasında pozitif yönlü orta $(p<0,05)$; Algılanan stres puanı ile ilişkilerde şeffaflık $(r=0,467)$, içselleştirilmiş ahlak anlayışı $(r=0,439)$, bilgiyi dengeli değerlendirme $(r=0,349)$, öz farkındalık $(r=0,426)$, otantik liderlik $(r=0,513)$ puanları arasında pozitif yönlü orta kuvvetli ilişki bulunmaktadır $(p<0,05)$.

Yapılan Pearson Korelasyon analizi sonucunda bazılarında zayıfta olsa bağımlı ve bağımsız değişkenler arasında ilişkinin olduğu tespit edilerek bütün hipotezlerin kabul edilmesi mümkündür. Ancak hangi bağımlı değişkenlerin, hangi bağımsız değişkenler ile açıklanabileceği ve ilişkinin derecesinin ne olduğunu saptamak üzere Regresyon analizi yapılmış ve sonuçları tablo 4 'te verilmiştir. 
T.C. Sağlık Bakanlığı Ulusal Medikal Kurtarma Ekibi (UMKE) Çalışanlarında Algılanan Stres Düzeyleri Üzerinde Otantik Liderlik Davranışları Etkisinin İncelenmesi: İstanbul İli Örneği

Examining the Effect of Authentic Leadership Behaviors on Perceived Stress Levels in National Medical Rescue Team (UMKE) Workers in the Ministry of Health: Example of Istanbul

Tablo 4. Algılanan Stres Boyutlarının Otantik Liderlik Boyutlarından Etkilenmesi

\begin{tabular}{|c|c|c|c|c|c|c|c|}
\hline \multirow{2}{*}{$\begin{array}{l}\text { Bağımlı } \\
\text { Değişken: } \\
\text { Algılanan Stres } \\
\text { boyutları }\end{array}$} & \multirow{2}{*}{$\begin{array}{l}\text { Bağımsız Değişken: } \\
\text { Otantik liderlik } \\
\text { boyutları }\end{array}$} & \multicolumn{3}{|c|}{ Katsayılar } & \multicolumn{3}{|c|}{ Model } \\
\hline & & B & $t$ & p & $\mathbf{F}$ & p & $\mathbf{R}^{2}$ \\
\hline \multirow{4}{*}{$\begin{array}{l}\text { Stres/Rahatsızlık } \\
\text { Algısı }\end{array}$} & $\begin{array}{l}\text { Sabit } \\
\text { Illişkilerde Şeffaflık }\end{array}$ & $\begin{array}{c}(13,197) \\
(\mathbf{0}, 274)\end{array}$ & $\begin{array}{l}(11,453) \\
(3,831)\end{array}$ & $\begin{array}{l}\left(0,000^{*}\right) \\
\left(0,000^{*}\right)\end{array}$ & \multirow{4}{*}{$(11,752)$} & \multirow{4}{*}{$(0,000)$} & \multirow{4}{*}{$(0,099)$} \\
\hline & $\begin{array}{l}\text { İçselleştirilmiş Ahlak } \\
\text { Anlayışı }\end{array}$ & $(0,034)$ & $(0,359)$ & $(0,719)$ & & & \\
\hline & $\begin{array}{l}\text { Bilgiyi Dengeli } \\
\text { Deăerlendirme }\end{array}$ & $(0,016)$ & $(0,135)$ & $(0,893)$ & & & \\
\hline & Öz Farkındalık & $(0,087)$ & $(0,995)$ & $(0,320)$ & & & \\
\hline \multirow{4}{*}{$\begin{array}{l}\text { Yetersiz } \\
\text { Özyeterlilik } \\
\text { Algısı }\end{array}$} & $\begin{array}{l}\text { Sabit } \\
\text { İlişkilerde Şeffaflık }\end{array}$ & $\begin{array}{l}(13,167) \\
(0,266)\end{array}$ & $\begin{array}{c}(11,326) \\
(3,685)\end{array}$ & $\begin{array}{l}\left(0,000^{*}\right) \\
\left(0,000^{*}\right)\end{array}$ & \multirow{4}{*}{$(17,190)$} & \multirow{4}{*}{$(0,000)$} & \multirow{4}{*}{$<<(0,138)$} \\
\hline & $\begin{array}{l}\text { İçselleştirilmiş Ahlak } \\
\text { Anlayışı }\end{array}$ & $(0,130)$ & $(1,365)$ & $(0,173)$ & & & \\
\hline & $\begin{array}{l}\text { Bilgiyi Dengeli } \\
\text { Deăerlendirme }\end{array}$ & $(0,030)$ & $(0,255)$ & $(0,799)$ & & & \\
\hline & Öz Farkındalık & $(0,119)$ & $(1,343)$ & $(0,180)$ & & & \\
\hline
\end{tabular}

${ }^{*} p<0,05$ anlamlı etki var, $p>0,05$ anlamlı etki yok

Tablo 4'de görüldüğü gibi Stres/Rahatsızlık algısı boyutunun otantik liderlik boyutlarından etkilenme derecesinin belirlenmesi için kurulan model anlamlıdır $(f=11,752, p<0,05)$. İlişkilerde şeffaflık boyutu $(b=0,274, \quad p<0,05)$ Stres/Rahatsızlık algısı boyutunu pozitif etkilemekte iken içselleştirilmiş ahlak anlayışı, bilgiyi dengeli değerlendirme, öz farkındalık boyutları etkilememektedir $(p>0,05)$. Stres/Rahatsızlık algısı boyutundaki değişimin $(\% 10,01)$ 'ini ilişkilerde şeffaflık boyutu açıklamaktadır. Yetersiz özyeterlilik algısı boyutunun otantik liderlik boyutlarından etkilenmesinin testi için kurulan model anlamlıdır $(f=17,190$, $p<0,05)$. İlişkilerde şeffaflık $(b=0,266, p<0,05)$ yetersiz özyeterlilik algısı boyutunu pozitif etkilemekte iken içselleştirilmiş ahlak anlayışı, bilgiyi dengeli değerlendirme, özfarkındalık boyutları etkilememektedir $(p>0,05)$. Yetersiz özyeterlilik algısı boyutundaki değişimin $(\% 13,99)$ 'unu ilişkilerde şeffaflık ve öz farkındalık boyutları açıklamaktadır.

\section{SONUÇ ve ÖNERILER}

Çalışmamızda algılanan stres düzeyi ile otantik liderlik boyutları arasında pozitif yönlü ve orta düzeyde bir ilişki olduğu görülmüştür. Yapılan Pearson Korelasyon analizi sonucunda bazılarında zayıfta olsa bağımlı ve bağımsız değişken arasında ilişkinin olduğu tespit edilerek bütün hipotezlerin kabul edilmesi mümkündür. Bu anlamda başta ilişkilerde şeffaflık, içselleştirilmiş ahlak anlayışı ve öz farkındalık olmak üzere otantik liderlik boyutlarının tamamının algılanan stres boyutları üzerinde etkisinin bulunduğu söylenebilir. Stres/Rahatsızlık algısı boyutu ve yetersiz özyeterlilik algısı boyutunun otantik liderlik boyutlarından etkilenme derecesinin belirlenmesi için kurulan model anlamlı bulunmuş olup, UMKE çalışanları otantik liderlik davranışları sergilediklerinde algı düzeylerinde olumlu etki olduğu anlaşılmaktadır. Özellikle UMKE yönelik otantik liderlik davranışlarını geliştirici faaliyetlerinin arttırıması; bakanlık kadrolarında karar verici mekanizmada bulunan yöneticilerin davranışlarını otantik liderlik davranışları doğrultusunda geliştirmeleri, çalışanların algılanan stres düzeylerini azaltıp, iş kalitesinin arttırılması için önerilmektedir. UMKE otantik liderlik davranışları göstermeleri çevrelerini olumlu yönde etkilediği söylenebilir. Ancak, algılanan stres çok çeşitli faktörlerden kaynaklanmakta olup, duruma ve kişiye göre değişmekte ve etkisi farklılık göstermektedir. Sağlık yönetiminde bulunan karar vericiler UMKE çalışanlarının algılanan stres düzeylerini azaltacak araştırmalara destek vermeleri gerekmektedir. UMKE çalışanlarının doğal afetlerde ve olağan dışı durumlarda 
görev yaptığı göz önünde tutulduğunda görev yaptıkları toplumun etik değerleri, anlayışları, bakış açıları, inançları gibi değerleri dikkate alarak otantik liderlik davranışları göstermeleri başarı oranını yükselteceği düşünülmektedir. Bu konuda yapılan çalışma literatür taraması sırasında rastlanılmaması araştırmanın önemini arttırdığı gibi bir kısıtlılık olarak algılanabilir. $\mathrm{Bu}$ konuda çalışma yapacak araştırmacılara, örneklem büyüklüğünü artırarak bölgeler arasında ve konunun yapısına uygun çalışmalar yapmalarını önerebiliriz. Ayrıca demografik özelliklerinde ayrıntılı olarak ele alındığı diğer liderlik tarzları ile de algılanan stres çalışılması önerilebilir.

\section{YAZAR NOTU}

Bu çalışma idRc2019 "Uluslararası Afet ve Dirençlilik Kongresinde (26 - 28 Haziran 2019, Eskişehir) bildiri olarak sunulmuştur. 


\section{KAYNAKLAR}

Çeri-Boom,S M. (2009). An Empirical Study on Transactional, Transformational and Authentic Leaders: Exploring the Mediating Role of Trust in Leader on Organizational Identification, Yeditepe Üniversitesi Sosyal Bilimler Enstitüsü, İstanbul (Yayımlanmış Doktora Tezi).

Eskin, M., Harlak, H., Demirkiran, F., \& Dereboy, Ç. (01.2013). Algılanan Stres Ölçeğinin Türkçeye Uyarlanması: Güvenirlik ve Geçerlik Analizi. In New/Yeni Symposium Journal , 51,132-140. http://yenisymposium.com/Pdf/EN-YeniSempozyum-c1d2631c.PDF

Gardner L.W., Avolıo, J.B., Luthans, F., May R.D., Walumbwa F. (2005). "Can You See the Real Me ? A Self-Based Model of Authentic Leader and Follower Development", The Leadership Quarterly, , 16:343-372.

Güçlü, N., (2001). “Stres Yönetimi”, G.Ü. Gazi Eğitim Fakültesi Dergisi, 21(1): 91-109.

Harter S. (2002). Authenticity, Oxford University Press, Oxford.

Işkın Y., Kaygın E. (2016). "Otantik Liderlik Anlayışının Örgütsel Bağlılık ve Örgütsel Yabancılaşmayla İlişkisi: Mobilya Sektöründe Bir Araştırma", Bartın Üniversitesi i.I.B.F. Dergisi, 7(14): 619-647.

Kernıs M. H. (2003). "Toward a Conceptualization of Optimal Self-Esteem", Psychological Inquiry, XIV, 1, 1-26.

Keser S. (2013). Illköğretim okulu yöneticilerinin otantik liderlik ve psikolojik sermaye özelliklerinin karşılaştırılması, Yıldız Teknik Üniversitesi, Sosyal Bilimler Enstitüsü, Eğitim Bilimleri Anabilim Dalı, İstanbul, (Yayınlanmış Yüksek Lisans Tezi).

Mark, G. M. and Smith, A. P. (2008). Stress models: A review and suggested new direction. Occupational health psychology, 3, 111-144.

Meyer P. J., Allen J.N. and Smith A.C. (1993). "Commitment to organizations and occupations: Extension and test of a three-component conceptualization", Journal of Applied Psychology, 78, 538-551.

Lazarus, R. S. (1991). "Psychological Stress İn The Workplace", Journal Of Social Behavior And Personality, 6, 1-13.

Leong, A.F. ve Cary L.C. (1996). "The Moderating Effect of Organizational Commitment on the Occupational Stress Outcome Relationship", Human Relations, Vol 49, No:10.

Selye H. (1974). Stress Wiıhout Disstress (New York: J.B. Uppencott Com.) 26,39

Ouıck, C. J. / Ooıck D. (1984). Organizational Stress and PrevenUve Management (New York: Mc Graw HillBook) 13,170.

Walumbwa O.F., Avolio B.J., Gardner W.L., Wernsing T.S., Peterson, S.J. (2008). "Authentic Leadership: Development and Validation of A Theory-Based Measure", Journal of Management, 34, 1, 89-126.

Yener S. (2018), "Psikolojik Rahatlık Algısının Otantik Liderliğin Sinizmin Üzerindeki Etkisinde Aracı Rolü", Eskişehir Osmangazi Üniversitesi I.I.B.F. Dergisi, C.13, s.1.1-14.

Yeşiltaş M., Kanten P. Ve Sormaz Ü. (2013). "Otantik liderlik tarzının prososyal hizmet davranışları üzerindeki etkisi: Konaklama işletmelerine yönelik bir uygulama", Journal of the School of Business Administration, Istanbul University, 42(2), s.336. 